\title{
IMPROVING ENERGY EFFICIENCY OF SILICON CARBIDE CERAMICS PRODUCTION BY BATCH REGULATION
}

\author{
Dmitriy Zhukov $^{1}$, Nikolay Makarov ${ }^{2}$, Maria Vartanyan ${ }^{3}$, Tatiana Guseva ${ }^{4}$
}

\begin{abstract}
The article discusses an energy-efficient method for producing SiC-based composites via doping with oxide eutectic compositions and batch granulometry regulation. The influence of batch granulometry on physicomechanical properties of ceramics is studied, and fractions ratio is determined allowing us to obtain a dense material with improved strength and fracture toughness. Such ceramics shows excellent mechanical behavior and holds much promise as a structural and armor material.
\end{abstract}

UDC Classification: 666.792.32:620.92, DOI: http://dx.doi.org/10.12955/cbup.v3.639

Keywords: silicon carbide, eutectic additive, energy efficiency, sintering temperature, mechanical strength, fracture toughness, armor materials

\section{Introduction}

Silicon carbide is a non-oxide compound that exhibits excellent toughness, wear resistance, heat conductivity, refractoryness, strength, low thermal expansion coefficient, significant oxidation resistance up to $1500{ }^{\circ} \mathrm{C}$, and chemical and corrosion resistance (Balkevich, 1984; Tretyakov, 1998; Matthews \& Rawlings, 2004). Its density is 2,5 times lower than that of steel. These features make silicon carbide desirable as a structural material in IC-engines, gas turbines, cutting tools, and ceramic bearings. Strong chemical bond makes it possible to apply this material as light armor since most part of kinetic energy in a rapid mechanical interaction between a bullet and an armor element is expended in opening chemical bonds within the material. Another notable feature of silicon carbide is its relatively low cost.

Processing of silicon carbide invokes temperatures up to $2150-2200^{\circ} \mathrm{C}$. Despite a wide range of applications for SiC-based ceramics, matters of energy and resource efficiency as well as constant demand for more reliable media stimulate a search for novelty materials with improved physicomechanical properties and reduced sintering temperature. Thus, one of the possible solutions here involves doping $\mathrm{SiC}$ with eutectic sintering aids.

The purpose of this study was to suggest an energy-saving and easily-implemented technique for manufacturing dense silicon carbide ceramics with tailored properties.

\section{Material and methods}

The sample batch consisted primarily of silicon carbide powder with mean grain size of $3-4 \mu \mathrm{m}$. Mean particle size in silicon carbide nanopowder was $45-55 \mathrm{~nm}$.

Candidate oxide eutectic systems for the present research included $\mathrm{CaO}-\mathrm{Al}_{2} \mathrm{O}_{3}-\mathrm{Y}_{2} \mathrm{O}_{3}, \mathrm{Al}_{2} \mathrm{O}_{3}-\mathrm{ZrO}_{2}$, and $\mathrm{MgO}-\mathrm{Al}_{2} \mathrm{O}_{3}-\mathrm{Y}_{2} \mathrm{O}_{3}$. Additives in $\mathrm{CaO}-\mathrm{Al}_{2} \mathrm{O}_{3}-\mathrm{Y}_{2} \mathrm{O}_{3}$ and $\mathrm{Al}_{2} \mathrm{O}_{3}-\mathrm{ZrO}_{2}$ systems were prepared using respective oxides, which were blended in desired proportions and calcined to complete possible physico-chemical transformations. In $\mathrm{MgO}-\mathrm{Al}_{2} \mathrm{O}_{3}-\mathrm{Y}_{2} \mathrm{O}_{3}$ system, alumomagnesian spinel and yttrium-aluminum garnet were prepared separately - the prior by calcining a mixture of salts, the latter by heterophase precipitation in water solutions of yttrium and aluminum chlorides.

\footnotetext{
${ }^{1}$ Dmitriy Zhukov, Institute for High-Temperature Materials and Technologies, D.I. Mendeleyev University of Chemical Technology of Russia, vip@ muctr.ru

${ }^{2}$ Nikolay Makarov, Institute for High-Temperature Materials and Technologies, D.I. Mendeleyev University of Chemical Technology of Russia

${ }^{3}$ Maria Vartanyan, Institute for High-Temperature Materials and Technologies, D.I. Mendeleyev University of Chemical Technology of Russia

${ }^{4}$ Tatiana Guseva, Institute for High-Temperature Materials and Technologies, D.I. Mendeleyev University of Chemical Technology of Russia
} 
Pre-fabricated additives in $\mathrm{CaO}-\mathrm{Al}_{2} \mathrm{O}_{3}-\mathrm{Y}_{2} \mathrm{O}_{3}$ and $\mathrm{MgO}-\mathrm{Al}_{2} \mathrm{O}_{3}-\mathrm{Y}_{2} \mathrm{O}_{3}$ systems were mixed together with $\mathrm{SiC}$ powder in calculated proportions. The batch was prepared in a vibro-mill with PTFE chambers with alumina grinding media in acetone. Slurries were dried at room temperature and passed through a 05 (approx. $30 \mathrm{BSS}$ mesh) sieve. A hot solution of paraffin in $\mathrm{CCl}_{4}(5 \%$ wt.) was used as binder, whereas mineral component was added portionwise and heated till complete solvent evaporation. Samples of different shape (disks and blocks) were uniaxially cold-pressed at $100 \mathrm{MPa}$ and fired at $1900^{\circ} \mathrm{C}$ in Argon with preliminary calcination at $700{ }^{\circ} \mathrm{C}$ in carborundum electric furnace in air.

\section{Results and discussion}

The resulting structural properties (i.e., density and porosity) and mechanical characteristics are presented in Table 1.

\begin{tabular}{|c|c|c|c|}
\hline \multirow{2}{*}{ Batch composition } & \multicolumn{3}{|c|}{ Parameters } \\
\hline & $\rho, \mathbf{g} / \mathbf{c m}^{3}$ & $\mathbf{P}_{0}, \%$ & $\sigma_{\text {bend }}, \mathrm{MPa}$ \\
\hline $\mathrm{SiC}+15 \%$ wt. $\mathrm{CaO}-\mathrm{Al}_{2} \mathrm{O}_{3}-\mathrm{Y}_{2} \mathrm{O}_{3}$ & 2.56 & 38.0 & $70 \pm 22$ \\
\hline $\mathrm{SiC}+20 \%$ wt. $\mathrm{CaO}-\mathrm{Al}_{2} \mathrm{O}_{3}-\mathrm{Y}_{2} \mathrm{O}_{3}$ & 2.58 & 34.0 & $82 \pm 24$ \\
\hline $\mathrm{SiC}+15 \%$ wt. $\mathrm{MgO}-\mathrm{Al}_{2} \mathrm{O}_{3}-\mathrm{Y}_{2} \mathrm{O}_{3}$ & 2.60 & 34.0 & $100 \pm 20$ \\
\hline $\mathrm{SiC}+20 \%$ wt. $\mathrm{MgO}-\mathrm{Al}_{2} \mathrm{O}_{3}-\mathrm{Y}_{2} \mathrm{O}_{3}$ & 2.70 & 28.0 & $120 \pm 22$ \\
\hline $\mathrm{SiC}+15 \%$ wt. $\mathrm{Al}_{2} \mathrm{O}_{3}-\mathrm{ZrO}_{2}$ & 2.64 & 33.0 & $100 \pm 24$ \\
\hline $\mathrm{SiC}+20 \%$ wt. $\mathrm{Al}_{2} \mathrm{O}_{3}-\mathrm{ZrO}_{2}$ & 2.69 & 30.0 & $110 \pm 20$ \\
\hline
\end{tabular}

Source: Authors

The increase of sample density correlated with additive content changing from 15 to $20 \%$ wt. for $\mathrm{CaO}$ $-\mathrm{Al}_{2} \mathrm{O}_{3}-\mathrm{Y}_{2} \mathrm{O}_{3}, \mathrm{Al}_{2} \mathrm{O}_{3}-\mathrm{ZrO}_{2}$, and $\mathrm{MgO}-\mathrm{Al}_{2} \mathrm{O}_{3}-\mathrm{Y}_{2} \mathrm{O}_{3}$ systems; however, this parameter was still below the value for undoped silicon carbide. The additive in $\mathrm{MgO}-\mathrm{Al}_{2} \mathrm{O}_{3}-\mathrm{Y}_{2} \mathrm{O}_{3}$, ceteris paribus, provided for a denser and less porous material. Mechanical strength and open porosity of ceramics with magnesia-based sintering aid were by an average $15 \mathrm{MPa}$ higher and 5\% lower, respectively, than those of ceramics with Ca-based additive or alumina-zirconia composition for the same additive content. Still, the obtained material displayed significant porosity and poor mechanical properties.

In order to improve mechanical characteristics of the developed material, the following hypothesis was provisionally accepted as a basis for further research. For general provisions for closest particle packing in bimodal distribution, Poluboyarinov \& Rutman (1966) suggested that the desired particle size ratio should be 10:1. Assumed that coarse fraction was presented by $\alpha-\mathrm{SiC}$ with mean particle size of $3-5 \mu \mathrm{m}$ and fine fraction, by eutectic additive with mean particle size of $300-500 \mathrm{~nm}$, the effect of fractions ratio on density was studied for samples pressed at 100 and $200 \mathrm{MPa}$. True densities of the additives were considerably different; hence, fractions ratio mentioned above was only applicable in terms of volume fractions. The content of fine fraction varied from 15 to $50 \%$ vol. in 5\% increments. The resulting densities are shown in Table 2 .

As the experimental data suggest, the densest materials were obtained at fraction ratio of 70:30, both for 100 and $200 \mathrm{MPa}$ (Batch No. 3). Further study was carried out on compositions with 30\% vol. of eutectic additives in $\mathrm{CaO}-\mathrm{Al}_{2} \mathrm{O}_{3}-\mathrm{Y}_{2} \mathrm{O}_{3}, \mathrm{Al}_{2} \mathrm{O}_{3}-\mathrm{ZrO}_{2}$, and $\mathrm{MgO}-\mathrm{Al}_{2} \mathrm{O}_{3}-\mathrm{Y}_{2} \mathrm{O}_{3}$ systems. Samples were pressed at $200 \mathrm{MPa}$ and fired at $1900{ }^{\circ} \mathrm{C}$ in Argon. Experimental variables included open porosity, mean density, and bending strength (see Table 3). 
CBU INTERNATIONAL CONFERENCE ON INNOVATION, TECHNOLOGY TRANSFER AND EDUCATION

\begin{tabular}{|c|c|c|c|c|c|c|}
\hline \multirow[b]{2}{*}{ Batch No. } & \multicolumn{2}{|c|}{ Composition, \% vol. } & \multicolumn{2}{|c|}{ Pressure - 100 MPa } & \multicolumn{2}{|c|}{ Pressure - 200 MPa } \\
\hline & $\begin{array}{c}\mathrm{SiC} \\
3-5 \mu \mathrm{m}\end{array}$ & $\begin{array}{c}\text { Dopant } \\
300-500 \mathrm{~nm}\end{array}$ & $\rho, g / \mathbf{c m}^{3}$ & $\mathbf{P}_{\mathbf{0}}, \%$ & $\rho, \mathbf{g} / \mathbf{c m}^{3}$ & $\mathbf{P}_{0}, \%$ \\
\hline \multicolumn{7}{|c|}{$\mathrm{CaO}-\mathrm{Al}_{2} \mathrm{O}_{3}-\mathrm{Y}_{2} \mathrm{O}_{3}$ additive } \\
\hline 1 & 85 & 15 & 2.06 & 38.0 & 2.14 & 35.4 \\
\hline 2 & 80 & 20 & 2.17 & 35.5 & 2.27 & 32.3 \\
\hline 3 & 70 & 30 & 2.33 & 32.4 & 2.40 & 30.1 \\
\hline 4 & 60 & 40 & 2.28 & 35.3 & 2.38 & 32.5 \\
\hline 5 & 50 & 50 & 2.12 & 41.2 & 2.32 & 35.6 \\
\hline \multicolumn{7}{|c|}{$\mathrm{MgO}-\mathrm{Al}_{2} \mathrm{O}_{3}-\mathrm{Y}_{2} \mathrm{O}_{3}$ additive } \\
\hline 1 & 85 & 15 & 2.13 & 37.2 & 2.22 & 34.4 \\
\hline 2 & 80 & 20 & 2.25 & 34.8 & 2.35 & 31.8 \\
\hline 3 & 70 & 30 & 2.44 & 31.6 & 2.52 & 29.5 \\
\hline 4 & 60 & 40 & 2.43 & 34.1 & 2.52 & 31.6 \\
\hline 5 & 50 & 50 & 2.30 & 39.7 & 2.53 & 33.8 \\
\hline \multicolumn{7}{|c|}{$\mathrm{Al}_{2} \mathrm{O}_{3}-\mathrm{ZrO}_{2}$ additive } \\
\hline 1 & 85 & 15 & 2.21 & 36.1 & 2.30 & 33.6 \\
\hline 2 & 80 & 20 & 2.33 & 34.2 & 2.48 & 30.2 \\
\hline 3 & 70 & 30 & 2.59 & 30.4 & 2.65 & 28.7 \\
\hline 4 & 60 & 40 & 2.57 & 34.1 & 2.68 & 31.1 \\
\hline 5 & 50 & 50 & 2.51 & 38.4 & 2.71 & 33.3 \\
\hline
\end{tabular}

Source: Authors

Consequently, the eutectic additive content of $30 \%$ vol. is not sufficient for considerable densification and strengthening of the material. Supposedly, silicon carbide in use was not active for sintering enough to obtain ceramics with improved mechanical properties; gaps between larger SiC grains were too wide to be healed during sintering.

\begin{tabular}{|c|c|c|c|}
\hline \multirow{2}{*}{ Batch composition } & \multicolumn{3}{|c|}{ Parameters } \\
\hline & $\rho, \mathrm{g} / \mathrm{cm}^{3}$ & $\mathbf{P}_{0}, \%$ & $\sigma_{\text {bend }}, \mathrm{MPa}$ \\
\hline $\mathrm{SiC}+\mathrm{CaO}-\mathrm{Al}_{2} \mathrm{O}_{3}-\mathrm{Y}_{2} \mathrm{O}_{3}$ & 2.73 & 30.2 & $94 \pm 22$ \\
\hline $\mathrm{SiC}+\mathrm{MgO}-\mathrm{Al}_{2} \mathrm{O}_{3}-\mathrm{Y}_{2} \mathrm{O}_{3}$ & 2.84 & 24.2 & $132 \pm 26$ \\
\hline $\mathrm{SiC}+\mathrm{Al}_{2} \mathrm{O}_{3}-\mathrm{ZrO}_{2}$ & 3.07 & 26.3 & $126 \pm 24$ \\
\hline
\end{tabular}

Source: Authors

Further tuning of ceramics properties was carried out on compositions with trimodal particle size distribution corresponding to the closest trimodal packing principle (particle size ratio - 100:10:1) (Poluboyarinov \& Rutman, 1966). Coarse grain size comprising $3-5 \mu \mathrm{m}$, the finest fraction in such compositions should not exceed $30-50 \mathrm{~nm}$. This finest fraction was presented by silicon carbide nanopowder with mean particle size of $45-55 \mathrm{~nm}$. Intermediate fraction with mean particle size of 
$300-500 \mathrm{~nm}$, same as above, was presented by eutectic additives, which would not only intensify sintering but also form the closest particle packing in shaping. Silicon carbide nanopowder and intermediate fraction content varied from 10 to 20 and from 25 to $35 \%$ vol., respectively, in 5\% increments. The resulting structural characteristics are presented in Table 4.

As the experimental data suggest, density of trimodal batch samples was higher than that of the bimodal ones. The highest achieved densities corresponded to $20 \%$ vol. of silicon carbide nanopowder (n-SiC). If this value dropped to $10-15 \%$, a decrease in mean density and open porosity growth would occur.

With cost concerns in mind, the content of $\mathrm{n}-\mathrm{SiC}$ was kept as low as possible, and further work was carried out on $15 \%$ vol. compositions (see Table 5).

It was observed that implying ultrafine dopant makes way for a dramatic increase in structural and mechanical characteristics. Ceteris paribus, regardless of the eutectics content materials with $15 \%$ vol. of $\mathrm{n}$-SiC, exhibited greater strength and far lower open porosity compared to those for ceramics without nano-scale non-oxide constituent. Implementation of ultrafine additive seemingly modifies structure formation process on compacting stage, promotes sintering, and alters hardening mechanism, which results in increased mechanical strength of the composite material.

Still, ceramics with $15 \%$ vol. of $\mathrm{n}-\mathrm{SiC}$ remained porous, and taking into account experimental data on density and porosity of trimodal batches (see Table 4), it proved necessary to keep the dopant content at $20 \%$, as shown in Table 5 .

\begin{tabular}{|c|c|c|c|c|c|c|c|}
\hline \multirow[b]{2}{*}{ Batch No. } & \multicolumn{3}{|c|}{ Composition, $\%$ vol. } & \multicolumn{2}{|c|}{ Pressure - 100 MPa } & \multicolumn{2}{|c|}{ Pressure - 200 MPa } \\
\hline & $\begin{array}{c}\mathrm{SiC} \\
3-5 \mu \mathrm{m}\end{array}$ & $\begin{array}{c}\text { Dopant } \\
\text { 300-500 } \\
\text { nm }\end{array}$ & $\begin{array}{c}\text { n-SiC } \\
45-55 \\
n m\end{array}$ & $\rho, \mathbf{g} / \mathrm{cm}^{3}$ & $\mathbf{P}_{\mathbf{0}}, \%$ & $\rho, \mathbf{g} / \mathrm{cm}^{3}$ & $\mathbf{P}_{\mathbf{0}}, \%$ \\
\hline \multicolumn{8}{|c|}{$\mathrm{CaO}-\mathrm{Al}_{2} \mathrm{O}_{3}-\mathrm{Y}_{2} \mathrm{O}_{3}$ additive } \\
\hline 1 & 65 & 25 & 10 & 2.70 & 20.5 & 2.83 & 16.8 \\
\hline 2 & 60 & 30 & 10 & 2.73 & 20.5 & 2.86 & 17.0 \\
\hline 3 & 55 & 35 & 10 & 2.76 & 20.7 & 2.88 & 17.3 \\
\hline 4 & 60 & 25 & 15 & 2.75 & 19.2 & 2.91 & 14.4 \\
\hline 5 & 55 & 30 & 15 & 2.78 & 19.3 & 2.91 & 15.4 \\
\hline 6 & 50 & 35 & 15 & 2.76 & 20.6 & 2.90 & 16.7 \\
\hline 7 & 55 & 25 & 20 & 2.77 & 18.5 & 2.91 & 14.3 \\
\hline 8 & 50 & 30 & 20 & 2.81 & 18.4 & 2.95 & 14.1 \\
\hline 9 & 45 & 35 & 20 & 2.78 & 20.0 & 2.95 & 15.3 \\
\hline \multicolumn{8}{|c|}{$\mathrm{MgO}-\mathrm{Al}_{2} \mathrm{O}_{3}-\mathrm{Y}_{2} \mathrm{O}_{3}$ additive } \\
\hline 1 & 65 & 25 & 10 & 2.81 & 20.0 & 2.93 & 16.4 \\
\hline 2 & 60 & 30 & 10 & 2.85 & 20.1 & 2.97 & 16.8 \\
\hline 3 & 55 & 35 & 10 & 2.87 & 20.9 & 3.01 & 17.0 \\
\hline 4 & 60 & 25 & 15 & 2.84 & 18.9 & 3.01 & 14.2 \\
\hline 5 & 55 & 30 & 15 & 2.89 & 19.0 & 3.03 & 15.1 \\
\hline 6 & 50 & 35 & 15 & 2.89 & 20.4 & 3.04 & 16.2 \\
\hline 7 & 55 & 25 & 20 & 2.87 & 18.3 & 3.02 & 14.0 \\
\hline
\end{tabular}


CBU INTERNATIONAL CONFERENCE ON INNOVATION, TECHNOLOGY TRANSFER AND EDUCATION

\begin{tabular}{|c|c|c|c|c|c|c|c|}
\hline 8 & 50 & 30 & 20 & 2.92 & 18.3 & 3.07 & 14.1 \\
\hline 9 & 45 & 35 & 20 & 2.91 & 19.8 & 3.06 & 15.8 \\
\hline \multicolumn{7}{|c|}{$\mathrm{Al}_{2} \mathrm{O}_{3}-\mathrm{ZrO}_{2}$ additive } \\
\hline 1 & 65 & 25 & 10 & 2.91 & 19.9 & 3.04 & 16.3 \\
\hline 2 & 60 & 30 & 10 & 2.99 & 19.7 & 3.12 & 16.3 \\
\hline 3 & 55 & 35 & 10 & 3.03 & 20.5 & 3.17 & 16.8 \\
\hline 4 & 60 & 25 & 15 & 2.96 & 18.5 & 3.11 & 14.4 \\
\hline 5 & 55 & 30 & 15 & 3.03 & 18.7 & 3.17 & 14.9 \\
\hline 6 & 50 & 35 & 15 & 3.05 & 20.0 & 3.20 & 15.9 \\
\hline 7 & 55 & 25 & 20 & 2.96 & 18.5 & 3.13 & 14.0 \\
\hline 8 & 50 & 30 & 20 & 3.04 & 18.3 & 3.20 & 13.9 \\
\hline 9 & 45 & 35 & 20 & 3.07 & 19.4 & 3.25 & 14.8 \\
\hline Soury
\end{tabular}

Source: Authors

Density and porosity of the samples with $\mathrm{CaO}-\mathrm{Al}_{2} \mathrm{O}_{3}-\mathrm{Y}_{2} \mathrm{O}_{3}, \mathrm{MgO}-\mathrm{Al}_{2} \mathrm{O}_{3}-\mathrm{Y}_{2} \mathrm{O}_{3}$, and $\mathrm{Al}_{2} \mathrm{O}_{3}-$ $\mathrm{ZrO}_{2}$ eutectic additives were quite close regardless of the additive content. As for mechanical characteristics, in otherwise equal conditions ceramics with $\mathrm{MgO}-\mathrm{Al}_{2} \mathrm{O}_{3}-\mathrm{Y}_{2} \mathrm{O}_{3}$ additive exhibited higher values than that with $\mathrm{CaO}-\mathrm{Al}_{2} \mathrm{O}_{3}-\mathrm{Y}_{2} \mathrm{O}_{3}$ or $\mathrm{Al}_{2} \mathrm{O}_{3}-\mathrm{ZrO}_{2}$ eutectics. This observation remained true for all investigated trimodal fraction ratios, which clearly favored magnesia-based additive. According to experimental data, increasing the content of $\mathrm{CaO}-\mathrm{Al}_{2} \mathrm{O}_{3}-\mathrm{Y}_{2} \mathrm{O}_{3}, \mathrm{MgO}-\mathrm{Al}_{2} \mathrm{O}_{3}-\mathrm{Y}_{2} \mathrm{O}_{3}$, and $\mathrm{Al}_{2} \mathrm{O}_{3}-\mathrm{ZrO}_{2}$ additives from 25 to $30 \%$ vol. had little effect on structural properties but significantly augmented bending strength of the material. Values obtained for the composition with $20 \%$ vol. n-SiC apprised LPSSiC armor parameters - almost zero open porosity and bending strength of $450 \pm 25 \mathrm{MPa}$. Thus, the most efficient experimental batch for armor applications among those studied was the one containing $30 \%$ vol. of $\mathrm{MgO}-\mathrm{Al}_{2} \mathrm{O}_{3}-\mathrm{Y}_{2} \mathrm{O}_{3}$ eutectic additive and $20 \%$ vol. $\mathrm{n}-\mathrm{SiC}$ dopant.

\begin{tabular}{|c|c|c|c|}
\hline \multirow{2}{*}{ Batch composition } & \multicolumn{3}{|c|}{ Parameters } \\
\hline & $\rho, \mathbf{g} / \mathrm{cm}^{3}$ & $\mathbf{P}_{\mathbf{0}}, \%$ & $\sigma_{\text {bend, }}, \mathbf{M P a}$ \\
\hline \multicolumn{4}{|c|}{$15 \%$ vol. $\mathrm{n}-\mathrm{SiC}$} \\
\hline $\mathrm{SiC}+25 \%$ vol. $\mathrm{CaO}-\mathrm{Al}_{2} \mathrm{O}_{3}-\mathrm{Y}_{2} \mathrm{O}_{3}$ & 3.08 & 9.5 & $220 \pm 25$ \\
\hline $\mathrm{SiC}+30 \%$ vol. $\mathrm{CaO}-\mathrm{Al}_{2} \mathrm{O}_{3}-\mathrm{Y}_{2} \mathrm{O}_{3}$ & 3.12 & 8.0 & $200 \pm 20$ \\
\hline $\mathrm{SiC}+25 \%$ vol. $\mathrm{MgO}-\mathrm{Al}_{2} \mathrm{O}_{3}-\mathrm{Y}_{2} \mathrm{O}_{3}$ & 3.17 & 7.5 & $350 \pm 15$ \\
\hline $\mathrm{SiC}+30 \%$ vol. $\mathrm{MgO}-\mathrm{Al}_{2} \mathrm{O}_{3}-\mathrm{Y}_{2} \mathrm{O}_{3}$ & 3.29 & 5.0 & $310 \pm 20$ \\
\hline $\mathrm{SiC}+25 \%$ vol. $\mathrm{Al}_{2} \mathrm{O}_{3}-\mathrm{ZrO}_{2}$ & 3.22 & 8.5 & $285 \pm 20$ \\
\hline $\mathrm{SiC}+30 \%$ vol. $\mathrm{Al}_{2} \mathrm{O}_{3}-\mathrm{ZrO}_{2}$ & 3.36 & 6.5 & $300 \pm 15$ \\
\hline \multicolumn{4}{|c|}{$20 \%$ vol. $\mathrm{n}-\mathrm{SiC}$} \\
\hline $\mathrm{SiC}+25 \%$ vol. $\mathrm{CaO}-\mathrm{Al}_{2} \mathrm{O}_{3}-\mathrm{Y}_{2} \mathrm{O}_{3}$ & 3.33 & 1.2 & $380 \pm 20$ \\
\hline $\mathrm{SiC}+30 \%$ vol. $\mathrm{CaO}-\mathrm{Al}_{2} \mathrm{O}_{3}-\mathrm{Y}_{2} \mathrm{O}_{3}$ & 3.35 & 1.3 & $355 \pm 15$ \\
\hline $\mathrm{SiC}+25 \%$ vol. $\mathrm{MgO}-\mathrm{Al}_{2} \mathrm{O}_{3}-\mathrm{Y}_{2} \mathrm{O}_{3}$ & 3.42 & 0.4 & $450 \pm 25$ \\
\hline $\mathrm{SiC}+30 \%$ vol. $\mathrm{MgO}-\mathrm{Al}_{2} \mathrm{O}_{3}-\mathrm{Y}_{2} \mathrm{O}_{3}$ & 3.47 & 0.3 & $400 \pm 25$ \\
\hline $\mathrm{SiC}+25 \%$ vol. $\mathrm{Al}_{2} \mathrm{O}_{3}-\mathrm{ZrO}_{2}$ & 3.50 & 0.5 & $400 \pm 20$ \\
\hline
\end{tabular}


CBU INTERNATIONAL CONFERENCE ON INNOVATION, TECHNOLOGY TRANSFER AND EDUCATION

\begin{tabular}{|l|c|c|c|}
\hline $\mathrm{SiC}+30 \%$ vol. $\mathrm{Al}_{2} \mathrm{O}_{3}-\mathrm{ZrO}_{2}$ & 3.56 & 0.7 & $380 \pm 20$ \\
\hline Source: Authors
\end{tabular}

The experimental procedure also included studies of physico-mechanical features relevant to armor construction, i.e. fracture viscosity, elasticity modulus, and micro-hardness. The results are presented in Table 6. As expected, ceramics with $\mathrm{n}-\mathrm{SiC}+30 \%$ vol. $\mathrm{MgO}-\mathrm{Al}_{2} \mathrm{O}_{3}-\mathrm{Y}_{2} \mathrm{O}_{3}$ eutectic additive demostrated the highest performance capabilities and was adopted for armor material. Microstructure of such ceramics is shown in Figure 1.

\begin{tabular}{|l|c|c|c|}
\hline \multicolumn{3}{|c|}{ Table 6: Structural and mechanical properties of armor material containing 20\% vol. n-SiC } \\
\hline \multicolumn{3}{|c|}{ Batch composition } & \multicolumn{3}{|c|}{ Parameters } \\
\cline { 2 - 4 } & $\begin{array}{c}\text { Fracture viscosity } \\
\mathbf{K}_{\mathbf{1 C}} \text {, } \mathbf{M P a} \cdot \mathbf{m}^{\mathbf{1 / 2}}\end{array}$ & $\begin{array}{c}\text { Elasticity } \\
\text { modulus, GPa }\end{array}$ & $\begin{array}{c}\text { Vickers hardness } \\
\mathbf{H}, \mathbf{G P a}\end{array}$ \\
\hline $\mathrm{SiC}+25 \%$ vol. $\mathrm{CaO}-\mathrm{Al}_{2} \mathrm{O}_{3}-\mathrm{Y}_{2} \mathrm{O}_{3}$ & 3.8 & 345 & 18.4 \\
\hline $\mathrm{SiC}+30 \%$ vol. $\mathrm{CaO}-\mathrm{Al}_{2} \mathrm{O}_{3}-\mathrm{Y}_{2} \mathrm{O}_{3}$ & 3.7 & 340 & 18.6 \\
\hline $\mathrm{SiC}+25 \%$ vol. $\mathrm{MgO}-\mathrm{Al}_{2} \mathrm{O}_{3}-\mathrm{Y}_{2} \mathrm{O}_{3}$ & 4.0 & 380 & 19.4 \\
\hline $\mathrm{SiC}+30 \%$ vol. $\mathrm{MgO}-\mathrm{Al}_{2} \mathrm{O}_{3}-\mathrm{Y}_{2} \mathrm{O}_{3}$ & 4.2 & 360 & 18.8 \\
\hline $\mathrm{SiC}+25 \%$ vol. $\mathrm{Al}_{2} \mathrm{O}_{3}-\mathrm{ZrO}_{2}$ & 3.7 & 350 & 17.4 \\
\hline $\mathrm{SiC}+30 \%$ vol. $\mathrm{Al}_{2} \mathrm{O}_{3}-\mathrm{ZrO}_{2}$ & 3.6 & 340 & 17.0 \\
\hline
\end{tabular}

Source: Authors

According to SEM data of specified ceramics, mean crystal size of silicon carbide was $3-6 \mu \mathrm{m}$; that of eutectic phases (alumomagnesian spinel, yttrium-aluminum garnet and corundum) was below $1 \mu \mathrm{m}$; nanoparticles of $\mathrm{SiC}$ did not exceed $60 \mathrm{~nm}$. Closed porosity was mostly intercrystalline, about $1-2 \%$ vol., with spherical pores; mean pore size was far below $1 \mu \mathrm{m}$.

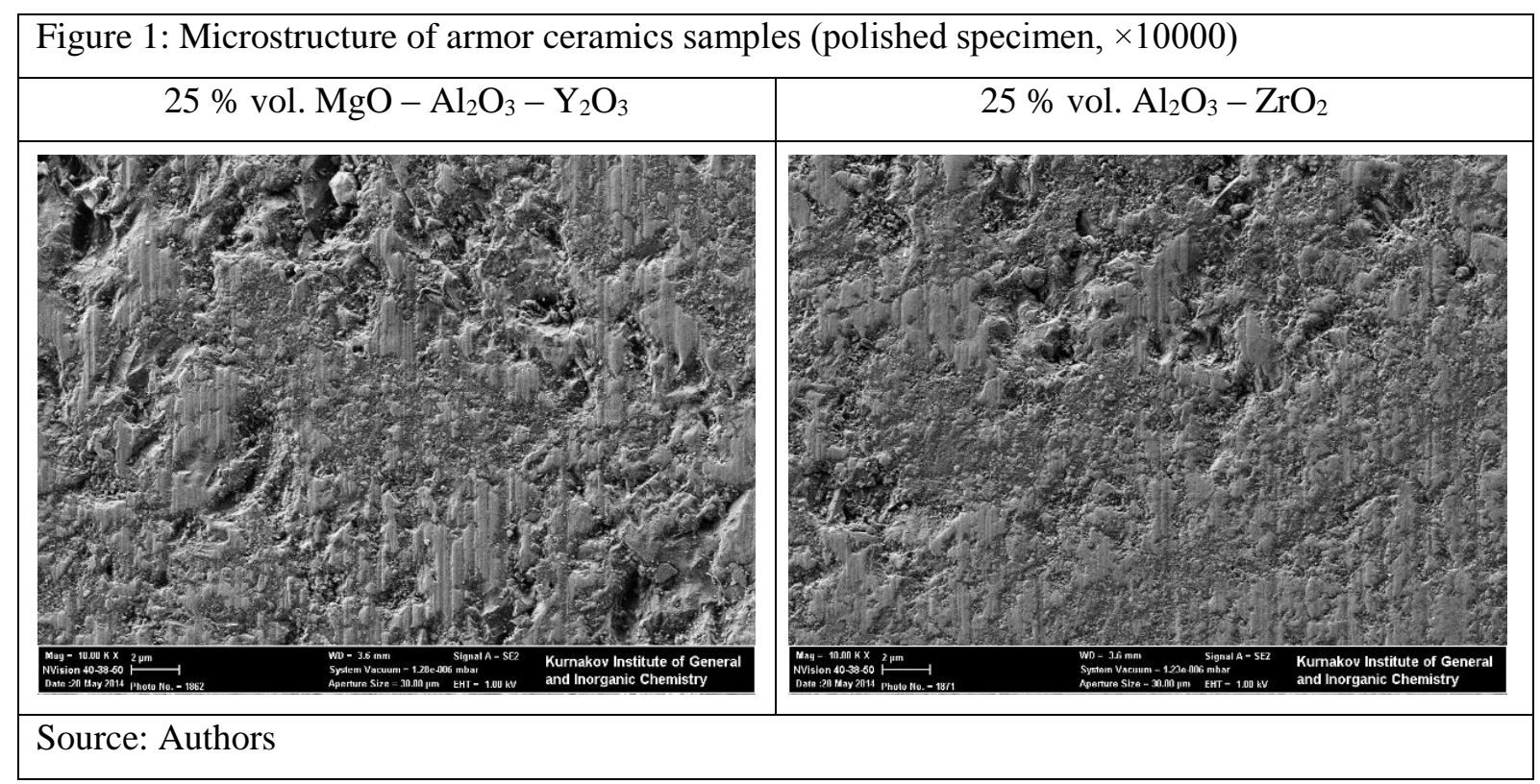

Another promising candidate for armor material would be ceramics with $30 \%$ vol. of $\mathrm{Al}_{2} \mathrm{O}_{3}-\mathrm{ZrO}_{2}$, (see Figure 1). According to SEM data of specified ceramics, mean crystal size of silicon carbide was $3-6 \mu \mathrm{m}$; that of eutectic phases was below $1 \mu \mathrm{m}$; sealed porosity was not observed. Particles of $\mathrm{n}-\mathrm{SiC}$ did not exceed $60 \mathrm{~nm}$. 


\section{Conclusion}

In the present study, patterns of physico-mechanical and structural properties of silicon carbide ceramics were examined. SiC-based compositions with 20\% vol. SiC nanopowder dopant and 30\% vol. eutectic additives in $\mathrm{MgO}-\mathrm{Al}_{2} \mathrm{O}_{3}-\mathrm{Y}_{2} \mathrm{O}_{3}$ and $\mathrm{Al}_{2} \mathrm{O}_{3}-\mathrm{ZrO}_{2}$ systems were suggested for potential use in producing ceramics for armor applications. Specified ceramic materials had sintering temperature of $1900^{\circ} \mathrm{C}$; a fine-grain structure and depending of the eutectic additive exhibited bending strength of $450 \pm 25$ and $400 \pm 20 \mathrm{MPa}$, microhardness of 18,8 and 17,0 GPa for magnesia-based and alumina-zirconia systems, respectively.

\section{Acknowledgement}

This research was conducted under the financial support from the Ministry of Education and Science of the Russian Federation within the framework of State order, contract No. 11.2056.2014/K.

Authors would like to express their gratitude to Olga Petrova, Assistant Professor at Chemistry and Technology of Crystals Dept., MUCTR, for her assistance in microhardness studies.

\section{References}

Balkevich, V. L. (1984). Advanced Ceramics (Russian). M.: Stroyizdat.

Matthews, F., \& Rawlings, R. (2004). Composite Materials: Engineering and Science (Russian). (Trans.). M.: Tekhnosphera. Poluboyarinov, D. N., \& Rutman, D. S. M. (Eds.) (1966). High-Refractory Materials (Russian). Metallurgiya.

Tretyakov, Yu. D. (1998). Ceramics in the Past, Present and Future. Soros Education Journal - Chemistry (Russian), 6, 5354. 